\title{
Testicular Seminoma, Tubular Variant
}

National Cancer Institute

\section{Source}

National Cancer Institute. Testicular Seminoma, Tubular Variant. NCI Thesaurus. Code C40959.

A morphologic variant of testicular seminoma characterized by the presence of seminoma cells arranged in tubular patterns and few lymphocytes. 